\title{
Refuge
}

Canada's Journal on Refugees

Revue canadienne sur les réfugiés

\section{Navigating Precarious Terrains: Reconceptualizing Refugee-Youth Settlement}

\section{Caitlin Nunn, Sandra M. Gifford, Celia McMichael and Ignacio Correa-Velez}

Volume 33, Number 2, 2017

URI: https://id.erudit.org/iderudit/1043062ar

DOI: https://doi.org/10.7202/1043062ar

See table of contents

Publisher(s)

Centre for Refugee Studies, York University

ISSN

0229-5113 (print)

1920-7336 (digital)

Explore this journal

Cite this article

Nunn, C., Gifford, S., McMichael, C. \& Correa-Velez, I. (2017). Navigating Precarious Terrains: Reconceptualizing Refugee-Youth Settlement. Refuge, 33(2), 45-55. https://doi.org/10.7202/1043062ar

\section{Article abstract}

Settlement is widely understood as the final stage of the refugee journey: a durable solution to forced displacement and a stable environment in which former refugees can rebuild their lives. However, settlement is shaped by rapidly changing socio-political forces producing contingent, unpredictable, and even hostile environments. This article draws upon Vigh's concept of social navigation to reconceptualize settlement as a continuation of a fraught journey in which refugee settlers must continually seek new strategies to pursue viable futures. We illustrate with an in-depth case study of the settlement journey of one refugee-background young man over his first eight years in Melbourne, Australia.
Copyright (c) Refuge: Canada's Journal on Refugees, 2017

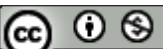

This document is protected by copyright law. Use of the services of Érudit (including reproduction) is subject to its terms and conditions, which can be viewed online.

https://apropos.erudit.org/en/users/policy-on-use/ 


\title{
Navigating Precarious Terrains:
}

\section{Reconceptualizing Refugee-Youth Settlement}

\author{
CAITLIN NUNN, SANDRA M. GIFFORD, CELIA MCMICHAEL, AND IGNACIO CORREA-VELEZ
}

\section{Abstract}

Settlement is widely understood as the final stage of the refugee journey: a durable solution to forced displacement and a stable environment in which former refugees can rebuild their lives. However, settlement is shaped by rapidly changing socio-political forces producing contingent, unpredictable, and even hostile environments. This article draws upon Vigh's concept of social navigation to reconceptualize settlement as a continuation of a fraught journey in which refugee settlers must continually seek new strategies to pursue viable futures. We illustrate with an in-depth case study of the settlement journey of one refugee-background young man over his first eight years in Melbourne, Australia.

\section{Résumé}

Létablissement est presque toujours comprise comme létape finale du voyage d'un réfugié, soit une solution pérenne à un déplacement forcé et un environnement stable dans lequel des ex-réfugiés peuvent reconstruire leur vie. Elle est cependant déterminée par des forces sociopolitiques rapidement évolutives pouvant générer des environnements contingents, imprévisibles, voire hostiles. Cet article s'inspire du concept de navigation sociale de Vigh pour reconceptualiser létablissement comme la continuation d'un voyage semé d'embûches, au cours duquel le réfugié colon doit continuellement être à la recherche de nouvelles stratégies pour établir un avenir pérenne. Nous illustrons cette perspective par l'étude approfondie des efforts d'établissement d'un homme jeune originairement réfugié, au cours de ses huit premières années à Melbourne, Australie.

\section{Introduction ${ }^{1}$}

W hen we first met Abraham he was seventeen years old. He had recently been resettled in Melbourne, Australia via the Humanitarian Program, having fled Ethiopia as a refugee. As part of his involvement in Good Starts, a longitudinal study of the settlement of refugee-background young people, ${ }^{2}$ we asked Abraham to draw his self-portrait. He depicted himself as a young man with a huge head and a big smile, standing shirtless and alone on a small boat, adrift on open water. Two thought bubbles read, "One day I will be a man. That day is far for me!!!!" and "I am very happy! But I have a lot to cope with!!!” There is a paddle in the boat, but it is lying unused at the bow (see figure 1).

Eight years later, Abraham still has his drawing. When we visit him for an interview he brings it out, and while discussing the challenges he faced in his first years of settlement, he explains, "So that was my stress drawing, that big-head man picture, because I'm happy-see the smiley face-and also there is a lot of shit-that's why my head is so big. And I'm on the water. Am I sinking or am I survive? Because I don't know shit about Australia."

Abraham's drawing powerfully evokes the experiences of many young people with refugee backgrounds as they embark on the settlement journey in Australia. ${ }^{3}$ Having arrived in Australia on permanent humanitarian visas, many find their horizons have opened up. With access to citizenship, education, health care, financial support, and much else, there is the possibility of pursuing a wide range of opportunities and aspirations. Yet in pursuing these possibilities they are faced with navigating multiple challenges posed by an unfamiliar, dynamic settlement terrain.

Abraham's drawing is also an apt illustration of the concept of social navigation, on which this article draws in order 


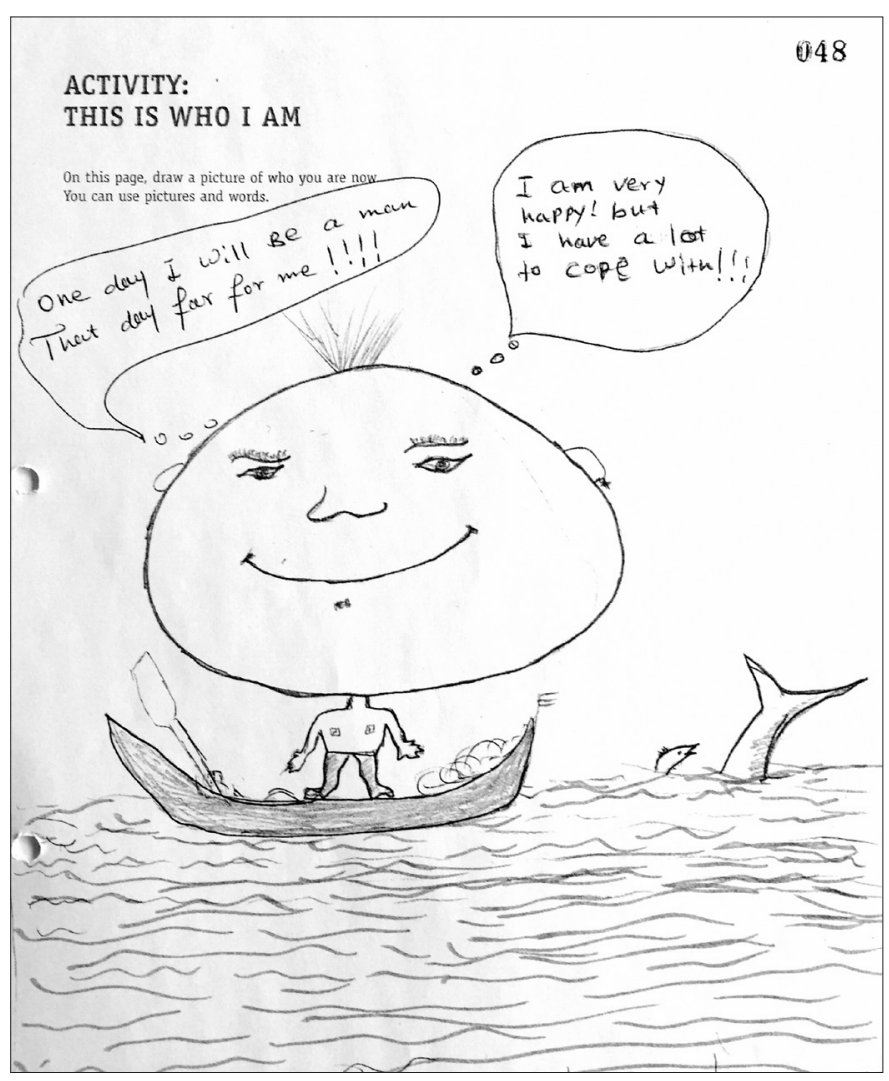

Figure 1: "This is who I am."

to reconceptualize settlement and how it is experienced among refugee-background youth in Australia. The concept of social navigation, as developed by Henrik Vigh, 4 emerges out of his ethnographic study of youth and soldiering in Guinea-Bissau, in which he explores the praxis of urban young men as they pursue social possibilities in a dynamic environment of conflict and poverty. Vigh advances the concept to capture "how people move and manage within situations of social flux and change." 5 In drawing on the metaphor of navigation as a process by which individuals move in and are moved by an ever-changing and often unpredictable environment, social navigation is highly relevant for considering refugee settlement; a context that is fluid and shaped by dynamic socio-political forces that in turn affect settlers' possibilities. Applying a social navigation lens to refugee youth settlement enables us to consider how these young people "simultaneously negotiate the immediate and the imagined," 6 addressing short-term needs and desires while also seeking to position themselves favourably in the pursuit of longer-term aspirations. In these ways, the concept of social navigation offers an alternative way to frame settlement: not as the endpoint of the refugee journey, but as ongoing negotiation of unstable, multiscalar socio-political terrains in the pursuit of viable futures.
We begin this article with a critical discussion of conventional understandings of refugee settlement. We then consider the ways in which Vigh's concept of social navigation offers a powerful approach for reconceptualizing refugee settlement, and more specifically, refugee-youth settlement. In the second section of this article we illustrate our argument through an in-depth case study of one refugeebackground young man, Matet, ${ }^{7}$ over the first eight years of his settlement experience in Melbourne, Australia. Matet is a participant in the Good Starts Study for Refugee Youth: a longitudinal study of 120 refugee-background young people over their first eight to nine years of settlement. ${ }^{8}$ An in-depth account of Matet's settlement journey provides a rich context for considering the power of applying a social navigation lens to contemporary refugee settlement. Through this case study, we demonstrate the interplay of diverse structural and agentive factors, and short- and long-term objectives and aspirations, in mediating the social possibilities of refugeebackground youth in settlement contexts. We conclude by arguing for a more critically engaged approach to refugee youth settlement: one that explicitly takes into account the precarity of this "durable" solution to forced displacementa solution that is rapidly becoming less durable within the context of mass forced displacement and closing national borders, and where the conventional refugee regime is increasingly under attack. ${ }^{9}$

\section{Refugee Settlement}

Settlement is conventionally understood as the final stage of the refugee journey: a process through which people with refugee backgrounds are integrated into, and gain the skills and knowledge to participate in, the country in which they are resettled. ${ }^{10}$ In Australia, the humanitarian settlement program is oriented to both short- and long-term objectives, addressing immediate needs while building humanitarian entrants' capacity for independence in the future. ${ }^{11}$ The parameters of settlement-both duration and objectivesare defined through government policy and associated service provision, with a focus on support over the first five years of settlement and on measurable outcomes, including learning English, participating in education, obtaining employment, and acquiring citizenship. ${ }^{12}$ Youth-focused settlement organizations highlight the distinct needs and experiences of this group during their teen and early adult years, including in education and employment, identity and belonging, and family relationships and intergenerational conflict. ${ }^{13}$

As Gifford and Kenny note, however, "What settlement is, how it is measured, experienced and achieved remains contentious,"14 and it is often differently conceptualized by governments and settlers. ${ }^{15}$ Conventional approaches that focus 
on measurable outcomes that can be addressed through specific interventions risk overlooking many important aspects of settlement. These include features that extend beyond short-term objectives-such as people's aspirations; factors that transcend the national sphere-such as transnational engagements; and issues that exist beyond direct service provision and policy-such as social connections, discrimination, and exclusion. ${ }^{16}$ Further, such outcome-focused definitions often fail to acknowledge the diversity among settlers, that "migrants' integration efforts, including their interaction with measures set out by integration policies, do not necessarily have a normative dimension." ${ }^{17}$

The United Nations High Commissioner for Refugees (UNHCR) - using the terminology of integration ${ }^{18}$-views refugee settlement as "a dynamic two-way process that places demands on both the refugee and the receiving community." 19 Valtonen suggests, however, that "refugee individuals and communities, as settlement actors, are the ones who are primarily enjoined to work toward bringing about specific conditions to facilitate their own integration." ${ }^{20}$ This reflects a tendency to envisage settlement as a unidirectional journey through static terrain, failing to acknowledge the changing social and political conditions into which refugees settle and the frequent non-linearity of their journeys. This limited conceptualization of settlement is given further credence by the dominance of cross-sectional "snapshot" studies that, in focusing on a moment in time, veil the dynamism of settlement processes and contexts. ${ }^{21}$ It is also reinforced by the tendency for policy to shape research agendas, encouraging attention to structural aspects of settlement and inhibiting critical engagement with government settlement policy, ${ }^{22}$ and by the overwhelming focus on people with refugee backgrounds as research subjects and settlement actors, with scant attention to other actors such as service providers, host societies, and diasporic communities. ${ }^{23}$ Indeed, in the Australian context, Neumann et al. argue that settlement research has increasingly narrowed in focus such that the field has not progressed significantly "towards a more informed and conceptually more sophisticated understanding of the settlement process." 24

\section{Settlement as Social Navigation}

Applying the concept of social navigation to the experiences of refugee youth in Australia provides insight into the changeable and often precarious nature of settlement in volatile local, national, and global socio-political environments. The premise of navigating these changing environments explicitly recognizes the dynamism of both the settlement journey and the social forces that shape it. It attends to refugee settlers as agents who not only move within their social environments, but are also shaped by the ways in which social environments move them, revealing their actions as "motion within motion." 25 Indeed, the power of social navigation as Vigh conceives it lies in its ability to capture in rich detail the ways in which his young male informants imagine their futures within a world that offers little but chronic violence and suffering-a world where their horizons are limited and often unpredictable. We draw on Vigh's concept of social navigation within contexts of precariousness because, while not as violent as the Guinea-Bissauan context of Vigh's research, young refugee settlers are making their present and future lives in a world that is changing and unpredictable, and where settlement in a country such as Australia does not necessarily deliver the promise of a safe and secure future. Instead, settlement is more accurately described as a process of navigating challenges and opportunities in an effort to move toward viable futures.

This approach to settlement moves beyond a narrow focus on policies and services facilitating integration, to one that makes visible diverse ways of navigating unstable, multi-faceted, and precarious settlement terrains. Social navigation offers a powerful alternative to conventional linear conceptualizations of refugee settlement, highlighting temporal dimensions, via the dual focus on the "immediate" (the realities of the present and proximate needs) and the "imagined" (aspirations and visions of the future). It draws attention to the Australian settlement environment as not necessarily stable, safe, or supportive; indeed, we argue that settlement is often precarious and fraught with risk. Social navigation allows us to understand settlement as a process by which people develop (or fail to develop) the skills and knowledge to successfully navigate their new host environment in their project of attaining viable futures. The concept of social navigation is a powerful way of understanding how refugee young people move through settlement-a terrain that is also in motion-as agents in making their lives and their futures, providing a powerful metaphor for describing the lived experiences of settlement in Australia.

We are not the first to draw attention to the merits of social navigation as a conceptual lens for rethinking refugee settlement. Denov and Bryan used the concept of social navigation in their study of settlement of separated children in Canada. ${ }^{26}$ They did so in order to draw attention to the agency of young people in the settlement process, and to frame discussion of the strategies their participants adopted in discrete settlement terrains, including in response to discrimination and loss. In this article, however, we provide a more nuanced and multi-faceted application of social navigation, considering its overall value for reconceptualizing refugee settlement. In doing so, we highlight the settlement process as one of uncertainty, unpredictability, and adversity and refugee youth settlers as individuals drawing on their 
resourcefulness in not only surviving in the present, but pursuing their imagined futures within this difficult context.

\section{Cohort and Context}

While the social flux in the lives of Vigh's Guinean interlocutors was profound, he stresses the wider applicability of the concept of social navigation: "We all navigate, but the intensity and visibility of our navigational efforts depend on the speed and/or opacity of social change and our ability to control oncoming movement. In other words, we all constantly struggle to gain the element of control that will allow for escape or positive engagement." 27

The dynamism of the refugee settlement context is not nearly as acute as in Guinea-Bissau. However, as with Vigh's interlocutors, young people with refugee backgrounds struggle for control over social environments and individual trajectories, exacerbated in their case by its unfamiliar and often conflicting elements.

The variables that mediate an individual's ability to navigate are multiple and "situationally defined." ${ }^{28}$ Refugee background is only one variable. Other intersecting variables include age, gender, race/ethnicity, education, and family and community relations. ${ }^{29}$ Social navigation therefore takes us beyond "refugee issues" to a more holistic and nuanced account of settlers within their socio-cultural histories and the terrain they navigate. ${ }^{30}$ Importantly, it emphasizes the dynamism of a terrain that is unpredictable and uncontrollable. In this way social navigation, as Vigh demonstrates, is particularly useful for analyzing the journeys of young people, who are in the process of "becoming" in a dynamic and often precarious socio-political landscape. ${ }^{31}$

\section{Moving through a Moving Environment}

The metaphor of the journey is often applied to refugee settlement, and refugee settlers are generally understood to be moving along a trajectory toward being "settled" or "integrated," however this may be understood. In contrast, the shifting terrain that is traversed during this journey is less frequently acknowledged, giving the impression that people with refugee backgrounds are settling into a stable social and political environment to which they must adapt.

Yet the settlement environment is always in flux-on the "micro, meso [and] macro level"32 - with changes to policy, service provision, host society reception, ideas of citizenship and belonging, homeland and ethnic community politics, and much else. ${ }^{33}$ Moreover, the pace and nature of change across the settlement terrain are highly uneven, such that settlers "may have stability in some areas of [their] lives and rapid change and uncertainty in others." 34 In Australia, this moving environment include changes to family reunion, citizenship laws, and public and political attitudes to refugees and asylum seekers. This instability can have profound effects on the trajectory of settlers, disrupting notions of a linear path to becoming "settled" in a stable environment. A social navigation approach explicitly acknowledges contexts where the socio-political environment is fraught with unpredictability and risk. Thus, applying a social navigation lens to refugee settlement reframes this process as one that involves "detours, unwilling displacement, losing [one's] way and ... redrawing trajectories and tactics," 35 and reframes settlers as individuals developing and applying their skills and knowledge to navigating a dynamic and precarious settlement context.

\section{The Interface between Agency and Social Forces}

Within research, policy, and practice there are conflicting perspectives on refugee agency. In the context of displacement, refugees are frequently constructed as passive victims, such that acts of agency-including resisting or expressing ingratitude for aid, or actively pursuing asylum in Western nations-are frequently met with suspicion and hostility. ${ }^{36}$ Yet in the settlement context, there remains a tendency to view those with refugee backgrounds from a deficit perspective, and at the same time, where refugees are expected to be the primary agents of their own settlement. ${ }^{37}$ Focusing on "the interface between agency and social forces," 38 a social navigation approach recognizes people with refugee backgrounds as active agents, while acknowledging the forces that mediate their social possibilities.

Social navigation can also take us beyond a context framed by formal settlement services and policies to capture the multiple forces that shape the broader terrain and trajectories of settlers. ${ }^{39}$ These may include local, national, diasporic, and transnational communities and politics. Consideration of these often-conflicting social forces is important for recognizing how refugee-background agents navigate them as they pursue their own settlement aspirations, and how these aspirations are shaped by-or in resistance to-the social forces at work within the wider world.

\section{The Socially Immediate and the Socially Imagined}

Refugee settlement involves both short- and long-term processes and goals. At times these immediate and longer-term pursuits are aligned. For example, acquiring safe housing provides a secure base from which to pursue education and employment into the future. Yet the short- and the longterm can also be in tension, particularly when time and resources are diverted from preparing for the future in order to address urgent needs. For example, refugee background youth often forego their longer-term education goals to earn money to support family in crisis overseas. As Vigh notes, "When the short term is unpredictable, less importance is 
given to the long term and there is a general feeling of a loss of agency" 40 This is a common experience for those from refugee backgrounds. ${ }^{41}$

Again, social navigation provides a conceptual framework for considering the immediate and the imagined within a dynamic settlement terrain, "encompass[ing] both the assessment of the dangers and possibilities of one's present position as well as the process of plotting and attempting to actualise routes into an uncertain and changeable future." 42 Importantly, it facilitates consideration of settlers' aspirations and how these mediate, and are mediated by, present circumstances.

\section{Navigation Knowledge and Skills}

For refugees, settlement requires new navigation skills, not only because the host environment is unfamiliar and often unstable, but also because the specific settlement tasks are new. For example, the school environment frequently differs from that in previous countries of residence and can present particular challenges for those who have limited or disrupted previous schooling. Vigh states, "A skilled navigator, social or otherwise, is able to adjust his [or her] knowledge of map, position and plot to a multiplicity of experienced and anticipated influences and forces." 43 However, if individuals do not or cannot acquire the requisite skills to successfully navigate the new settlement terrain, they risk venturing into troubled waters or being blown off course. Alternatively, if they fail to gain power over their own movement, they risk remaining dependent on others to set and maintain their trajectory. The result in both cases may be understood as a failure to setthe well—or not to settle at all. A social navigation approach thus draws attention to settlement-both as a terrain to be navigated and as a process of acquiring and applying skills and knowledge - in the pursuit of viable futures.

\section{Social Navigation in Action}

\section{The Good Starts Study}

Good Starts for Refugee Youth is a study of the settlement and well-being of refugee-background youth in Melbourne, Australia. In contrast to the majority of research on refugee settlement, which is cross-sectional or conducted at one point in time and ethno- or issue-specific, Good Starts is a longitudinal study of multiple aspects of settlement among an ethnically diverse cohort. The study was informed theoretically and methodologically by medical anthropology and social epidemiology and thus strived to gather qualitative and quantitative information from a cohort of newly arrived young people over time. This was important, as few longitudinal studies of migration and none of refugee settlement had used mixed methods to measure settlement outcomes and the predictors and at the same time, elicit in-depth qualitative data on the experiences of settlement over time. ${ }^{44}$
Beginning in 2004, 120 refugee youth aged between 11 and 19 years were recruited through English Language Schools, in which most newly arrived youth spend between six and twelve months during their first year in Australia. None of the participants arrived in Australia as unaccompanied minors, although few arrived with all of their immediate family members. Participants came from twelve different countries in Africa, the Middle East, and Europe, and were broadly representative of the population of young refugees arriving in Australia at that time. 45

Participants were followed annually across their first four years of settlement. A combination of qualitative and quantitative methods was used to explore participants' settlement journeys, with a particular focus on family and social support, education, health and well-being, and life in Australia. A fifth follow-up was conducted in 2012-13, when participants were between eight and nine years post-arrival. Fifty-one of the original 120 Good Starts participants were able to be contacted and interviewed for this follow-up, providing insights into longer-term settlement experiences and outcomes. ${ }^{6}$ Ethical clearance was given by the Human Ethics Committee of La Trobe University, the Institutional Ethics Committee of the Victorian Foundation for Survivors of Torture and Trauma (a study partner), and the Victorian Department of Education, Employment and Training. 47

The longitudinal nature of the study, as well as its focus on multiple aspects of settlement, enables a dynamic understanding of refugee settlement. While we have reported extensively on the experiences of the cohort as a whole, ${ }^{48}$ a deeper exploration of the lived experience of one individual through an in-depth case study ${ }^{49}$ offers a rich picture of settlement over time and facilitates insights into the conceptual value of social navigation for understanding refugee youth settlement. From among the 51 young adults who participated in the final wave of data collection, we have selected the story of one young man whose experiences broadly reflect the terrains navigated by members of this cohort. In attending to this particular case, the aim is not to "search for generality" but, as in case study research generally, "to try to capture the essence of the particular in a way we all recognise" through which "we come to understand the universal." ${ }^{50}$ At the eight-/nine-year follow up there was a range of settlement trajectories among participants, and for only a few could their settlement could be considered a sound success or failure. Although every individual story is unique, the common thread is a settlement journey full of unexpected turns, financial challenges, ongoing family fortunes and misfortunes in Australia and overseas, births of children and marriages, engagement with education and employment, return visits to regions of origin, and loss of loved ones still living in countries with civil unrest, violence, and hardship. 
We thus offer the story of a young Sudan-born ${ }^{51}$ Dinka man named Matet. The narrative is drawn from data collected across the duration of Matet's participation in the Good Starts Study, including field notes, written and visual activities including photo stories, ${ }^{52}$ short qualitative interviews over the follow-up period, and an in-depth qualitative interview conducted in the fifth follow-up, eight or nine years post arrival. While recognizing that this account, like all biographies, is constructed-first by Matet and then by the authors of this article ${ }^{3}$ - we focus on the important insights it provides into the complex interactions between agency and multiscalar social forces in the individual lives of refugee-background young people as they navigate the dynamic settlement terrain in pursuit of viable futures.

\section{Matet's Settlement Journey}

Matet describes himself as a young Dinka man. In early adolescence he fled his native Sudan to Egypt with his mother and three younger siblings. After almost two years, when Matet was 16 years old, they were accepted for resettlement in Australia, sponsored by his uncle, already in Australia, through the Special Humanitarian Program. ${ }^{54}$ Matet's father, a pastor, remained in Sudan. During his first years in Australia, Matet worried about being without his father, but he was supported by his school, church, friends, and ethnic community. He excelled at basketball and was captain of his school team. He aspired to complete university and become an engineer and to remain in Melbourne, buy a house, and have a family.

While things were going well in Matet's everyday life during this early period, his Sudanese community experienced traumatic events that altered their sense of security in Australia and Sudan-events that also had an unsettling impact on Matet. In July 2005, John Garang, Sudan's recently appointed vice president and leader of the Sudan People's Liberation Army-and a relative of Matet's-died in a helicopter crash. His death triggered riots and provoked fears for the fate of the fragile peace agreement between North and South Sudan and, across the Sudanese diaspora, fear for the safety of family members in Sudan. Two years later, a young man of Sudanese background, Liep Gony-a friend of Matet's - was murdered in a Melbourne suburb by non-Sudanese assailants. The media focused overwhelmingly, and negatively, on Sudanese Australians. A subsequent announcement by the immigration minister that Australia would cut resettlement from Africa, partly in response to the perceived failure of Sudanese people to settle successfully in Australia, provoked further negative attention on people with Sudanese backgrounds and undermined their sense of belonging in Australia. ${ }^{55}$ Each of these deaths unsettled the security of Sudanese Australians, causing anxiety in the community and threatening the safety of people in Sudan and Australia. For Matet, these were also felt personally as the loss of loved ones.

Matet's life changed more dramatically several years into settlement when his mother bought a house in a relatively affordable suburb on the other side of the city, and he had to relocate with his family. Matet wanted to stay in his neighbourhood and school, but felt he had to go: "I told her that I didn't want to, but there's no one I can stay here with, so I have to go with my family no matter what. And plus I'm the oldest and I can't leave them behind, let them go by themselves. So I have to leave the school and go with them."

Rather than completing the final year of his education at a new school, he put aside the advice of his teachers and left school to take up apprenticeship training in carpentry through a local TAFE. 56 "I did listen to them," Matet says of his teachers, "but when I got there I just had a feeling that I don't wanna go to any school." Already forced to move to a new suburb, the thought of starting a new school was too much for Matet. He enjoyed his new apprenticeship, however, and reoriented his aspirations toward becoming a carpenter.

Matet's new neighbourhood was in transition. Traditionally a socio-economically disadvantaged area, it was rapidly urbanizing and culturally diversifying. The negative reception among some sections of the wider Australian community to people of Sudanese background that came to the fore in the aftermath of Gony's death became a problem for Matet and his family in their new suburb, as "suddenly it started being [a] bad racist place." Raw eggs were thrown at their house, the windows were smashed, and Matet's younger siblings had objects thrown at them on their walk to school. The attacks on Matet's family culminated in his being hithe believes intentionally-by a neighbour's car. Despite the presence of a witness, the police did not pursue the matter, eroding Matet's confidence in them and in the justice system more broadly. Moreover, his leg was badly injured in the incident, leading him to drop out of his apprenticeship course. Soon after, out of fear, he moved from home, leaving his family and relocating to a regional town more than two hours away where he had other relatives. He resumed his apprenticeship studies there and also began playing basketball again with fellow students.

Things remained calm for awhile, but then Matet's longterm Nuer girlfriend, Nyabol, became pregnant. This caused significant tensions in both families as a result of the historical and ongoing conflicts between Dinka and Nuer people in their homeland. Matet and Nyabol defied their parents, and she moved in with him: "Well, just what I told my family is: 'I love her so I don't care what happened back then. You guys have gotta forget about it. Whatever happened back then happened, so let's just forget about it." 
Gradually, following the birth of their child, the families grew more accepting. However, a second child a few years later put financial strain on the couple and Matet had to give up his studies to seek paid work. The socio-economically disadvantaged regional town where he lived could not provide apprenticeship opportunities and, without a car or driver's licence, he was unable to travel. Instead, on the advice of the local government-contracted job-seeking centre, he undertook a hospitality certificate and accepted a job at a large Melbourne business, making the long commute by train.

Having continued in this way for several years, Matet, Nyabol, and their children finally saved enough money to rent a unit in a suburb close to where Matet's family originally settled, and they returned to Melbourne. Matet is still working as a kitchen hand but maintains his goal to become a carpenter. He has begun applying for jobs so he can finish his apprenticeship, but has had only one unsuccessful interview. Money is tight. Nyabol is not working, and they are saving for marriage 57 and also sending money to support relatives in Sudan. Overall, though, Matet describes himself as happy. He explains that family is the most important thing in his life, that he is in a loving and supportive relationship, his children are thriving, and relatives are constantly visiting. He has recently become friends with neighbours through the local church.

Nonetheless, beyond his home, church, local family, and friends, social forces continue to exert pressure on Matet, impeding his journey toward his own settlement horizons. Following the recent death of Matet's uncle, his father has asked him to return to South Sudan and take over his uncle's farming business. Matet has refused, unwilling to leave his own young family and to risk the continued dangers in the recently formed nation of South Sudan. At the same time, the death of a Melbourne-based relative has also caused disquiet. A young man fell to his death in a high-rise building, and Matet and others suspect it was at the hands of police with whom the deceased had dealings on the evening he died. For Matet, this suspicion is informed by his earlier experiences with police and by many other stories circulating in Melbourne's Sudanese communities. This perception of discrimination and persecution of Sudanese Australians troubles him deeply.

Despite these challenges, Matet remains hopeful. He describes his aspirations to have more children, visit Sudan, finish his apprenticeship, and work as a carpenter. He articulates clearly how his settlement journey has opened up opportunities to learn important skills and acquire the resources for navigating towards his imagined future: "Cause like with my high school and my studies I did make a decision that I regret ... I learned through that if I want to make a decision I'll have to make it wisely, choose wisely, and that's how I'm going through it. A lot of the time, if I want to make a decision I will think about it and then, if it's really hard, I will ask my partner to help me with it."

Eight years after arriving in Australia, Matet remains confident in his ability to navigate what lies ahead.

\section{Matet's Journey as Social Navigation}

Matet's personal journey tells a more general story about the dynamic forces that mediate the settlement of people with refugee backgrounds. It also demonstrates the agency of settlers in navigating this terrain-with varying degrees of success-and how, through the settlement process, skills, knowledge, and resources can be acquired to support the navigation of immediate circumstances in pursuit of social possibilities and viable futures.

Throughout his journey, Matet moves through a moving environment, with micro, meso, and macro social forces fluctuating across time and context, influencing his nonlinear settlement trajectory. Importantly, settlement is not the safe, predictable, and welcoming experience of starting a "new" life in Australia as commonly portrayed. On the contrary, although opportunities for secure housing, education, and employment are on offer, violence, racism, discrimination, family separation, and conflict in Australia and overseas continue to affect Matet's ability to take advantage of them. While Matet's participation in education and training is initially fostered by a supportive community, it is derailed several times by forces outside his control, including his mother's move to a new suburb in pursuit of affordable housing, discrimination by residents of that suburb who see Sudanese newcomers as a threat, and growing financial responsibility for a young family. Matet's sense of belonging in Australia has shifted dramatically from locating him at the centre of his school as captain of the basketball team to rendering him fearful for his safety in a local and national social environment that has become increasingly hostile toward people of Sudanese background, and refugee-background settlers more generally. The fragility of Sudanese belonging in Australia is a constant in Matet's life as he lives with the suspicious death of his relative. Despite these disruptions to his settlement journey, Matet narrates these challenges as always tempered by a loving and supportive family in the present and aspirations for a positive future.

While Matet is not entirely at the mercy of these social forces, he cannot always successfully navigate around and through them. However, he exhibits varying capacities to proactively or reactively respond to the social forces that act upon him. He articulates clearly what he has learnt in hindsight and how he will apply these lessons to pursuing his imagined future.

Matet's journey reveals how the project of settlement does not rest entirely with the settler. Myriad social forces 
shape settlement horizons locally, nationally, and transnationally. People's capacity to respond to these forces is situational, dependent on the knowledge, skills, and resources they can draw on to support their navigation of precarious settlement terrains. Capacities shift across time and are affected by life events such as starting a family. In this regard, Matet expresses his increasing confidence in resisting negative social forces, including cultural and familial pressures on his choice of a non-co-ethnic partner and his father's demands for him to return to South Sudan to take on family responsibilities. Matet becomes an increasingly proactive and skilled navigator of his settlement landscape, electing to return to Melbourne and to pursue his aspiration to become a carpenter.

Through all of these shifts-in social forces, agency, and trajectory-Matet's simultaneous negotiation of his immediate circumstances and imagined future is evident. Newly arrived in Australia, Matet aspired to attend university and have a house and a family within ten years of settling. While a combination of social forces and personal decisions steered him away from a university education, he recalibrated his education plans toward an apprenticeship and career in carpentry. He continues to pursue this possibility, though immediate needs and circumstances frequently compete for his attention and impede his progress. At the same time, however, his most constant future aspiration - to have a family-has long provided fixed coordinates to guide his journey, and it remains his motivation.

Through his settlement journey, Matet has gained skills, knowledge, and resources that support his navigation. These include decision-making skills learned through perceived errors of judgment, increasing his confidence in setting his own trajectory, and the constancy of family-both as a responsibility and as a support. Yet while Matet is confident in his ability to steer his everyday life, he continues to feel the impact of broader forces of discrimination and social exclusion in Australia and ongoing violence and conflict in his home country. This exposes the limits of agency in the settlement process and highlights the critical role of sociopolitical forces in shaping the experiences and trajectories of refugee-background youth.

\section{Navigating Contemporary Settlement}

While refugee settlement has never been the linear journey through stable terrain that it is often represented to be, it is becoming increasingly complex and precarious. Settlement-already a rare occurrence for less than 1 per cent of the world's refugee population-is becoming less accessible and less permanent. Pathways to citizenship are progressively limited in some nations-such as the UK, where refugee status is now reviewed after five years, ${ }^{58}$ and for some groups-such as onshore humanitarian arrivals in Australia (without a valid visa), who no longer have access to permanent humanitarian visas and thus will never be granted settlement in Australia, regardless of their refugee status determination. ${ }^{59}$ Further, the permanence of residency and citizenship for those born outside their country of residence is under greater threat, with many nation-states now seeking and invoking powers to revoke permanent residency and citizenship under certain conditions. ${ }^{60}$ These policy changes are occurring in a climate of global securitization as a key response to forced migration. This is further exacerbated by a political discourse that frequently conflates refugees with Islamic extremism, which can influence local reception of refugee settlers and mediate feelings and relations of (non-) belonging. ${ }^{61}$

Within settlement countries, migration and refugee settlement policies are also often in flux, with significant implications for settlers. In Australia, for example, the past decade has seen an extension of the duration of residency required prior to obtaining citizenship, increasing barriers to family reunion, and-reflecting trends in Europe and North America-a focus on settling refugees in regional areas outside traditional metropolitan settlement centres. ${ }^{62}$

Refugee settlers are also affected by broader national and global economic shifts that increase precarity, such as the decline of manufacturing sectors in many advanced economies-a traditional source of income for refugee settlers; increased workforce casualization and exploitation of refugee background employees-eroding financial security; and emphasis on further education-a challenge to those whose first language is other than English. ${ }^{63}$ These barriers to financial security are further compounded by decreasing housing affordability in many major cities in settlement countries. ${ }^{64}$

Beyond the country of settlement, people with refugee backgrounds are also negotiating a dynamic transnational sphere, including rapidly transforming homeland and diasporic politics and shifting relations, locations, and situations of friends and family. While this has always been the case for refugee settlers to some extent, the growing sophistication of, and access to, information and communication technologies and the increasing affordability of air travel has embedded these transnational forces into daily life in ways that were unimaginable during the last century. ${ }^{65}$

All of these factors contribute to an emerging state of what Vigh terms "chronic crisis" 66 for many refugee settlers, who are attempting to "make lives in fragmented and volatile worlds." ${ }^{67}$ In this unstable terrain of settlement, refugee settlers, regardless of personal agency, face uncertain possibilities, impeding their ability to confidently chart pathways to viable futures. Our longitudinal Good Starts Study reveals the particular impacts on young people who aspire to bright 
futures and the new social possibilities that settlement offers. While this sense of crisis has arguably increased significantly in recent years, we can already see its traces in Matet's account of settlement: in his family's pursuit of affordable housing, in the pressure to fulfil transnational familial obligations, and in his ongoing experience of anti-Sudanese/refugee sentiment in the Australian community. While Matet's story captures his own unique experiences, his uneven navigation of diverse settlement landscapes, including education, racism, family, and homeland, resonates with the experiences of Good Starts participants more generally.

In this article we have drawn on the concept of social navigation to reveal these challenges through a holistic account of refugee settlement. This concept is important because it engages explicitly with the dynamism of the settlement terrain, attending to the multiscalar social forces that mediate settlement, as well as the capacities of settlers to proactively and reactively engage with them. It renders visible the continual interplay of the short- and long-term objectives and aspirations of settlers as they move through settlement terrains over time. It additionally highlights the importance of settlement as a journey through which people with refugee backgrounds acquire knowledge, skills, and resources to support independent and confident navigation of future possibilities. Importantly, it disrupts the notion of settlement as a linear, finite journey that can be undertaken by all settlers. A social navigation perspective challenges the increasing emphasis on settlement as integration into an implicitly stable socio-national context, framing it instead as a process whereby people with refugee backgrounds navigate shifting social possibilities in pursuit of viable futures. Importantly, it destabilizes conceptualizations of settlement as a safe and secure durable solution and instead reveals the inherent and growing precariousness of the refugee settlement regime.

It is critical that we develop new ways of thinking that challenge the long-held perception of settlement as the endpoint of forced migration. As BenEzer and Zetter note, for refugees, "the journey often does not end with the physical arrival at the destination, and sometimes it does not end at all. It is contingent on many circumstances." 68 A social navigation approach, as we demonstrate, captures this in all of its complexity.

\section{Notes}

1 The authors would like to acknowledge the contribution of the young people who participated in the study, the staff from the English Language Schools, and the research team. Funding for the first four years of the Good Starts study was provided by VicHealth, Foundation House (VFST), Sydney Myer Fund, William Buckland Foundation, La
Trobe University, and, for the eight/nine-year follow-up, by the Australian Research Council (DP120101579).

2 Sandra M. Gifford, Christine Bakopanos, Ida Kaplan, and Ignacio Correa-Velez, "Meaning or Measurement? Researching the Social Contexts of Health and Settlement among Newly Arrived Refugee Youth in Melbourne, Australia," Journal of Refugee Studies 20, no. 3 (2007): 414-40; "The Good Starts Study for Resettled Refugee Youth in Australia," http://goodstarts.net.

3 Throughout the article we apply the un definition of youth as those aged between 15 and 24 years, while also "recognis[ing] 'youth' as a social construct reflecting local understandings." Rosalind Evans and Claudia Lo Forte, with Erika McAslan Fraser, UNHCR's Engagement with Displaced Youth: A Global Review (Geneva: UNHCR PDES, 2013), 9, http://www.unhcr.org/513f37bb9.pdf.

4 Henrik Vigh, Navigating Terrains of War: Youth and Soldiering in Guinea-Bissau (New York: Berghahn Books, 2006).

5 Henrik Vigh, "Motion Squared: A Second Look at the Concept of Social Navigation," Anthropological Theory 9, no. 4 (2009): 420.

6 Vigh, Navigating Terrains, 13.

7 Matet is a pseudonym to protect the identity of the participant.

8 Celia McMichael, Caitlin Nunn, Sandra M. Gifford, and Ignacio Correa-Velez, "Studying Refugee Settlement through Longitudinal Research: Methodological and Ethical Insights from the Good Starts Study," Journal of Refugee Studies 28, no. 2 (2014): 238-57; Gifford et al., "Meaning or Measurement?"

9 United Nations High Commissioner for Refugees (UNHCR), "Solutions," http://www.unhcr.org/uk/solutions.html; Alexander Betts and Paul Collier, Refuge: Transforming a Broken Refugee System (London: Penguin, 2017); Robin Cohen and Nicholas Van Hear, "Visions of Refugia: Territorial and Transnational Solutions to Mass Displacement," Planning Theory \& Practice 18, no. 3 (2017): 494-504.

10 Kathleen Valtonen, "From the Margin to the Mainstream: Conceptualizing Refugee Resettlement Processes," Journal of Refugee Studies 17, no. 1 (2004): 70-96.

11 UNHCR, The Integration of Resettled Refugees: Essentials for Establishing a Resettlement Programme and Fundamentals for Sustainable Resettlement Programmes, http://www .unhcr.org/52a6d85b6.html.

12 See, for example, Department of Social Services (Dss), "About Settlement Grants," http://www.dss.gov.au/ourresponsibilities/settlement-and-multicultural-affairs/ programs-policy/settlement-services/settlement-grants/ what-is-settlement-grants/about-settlement-grants.

13 Multicultural Youth Advocacy Network (MYAN), National Youth Settlement Framework (Melbourne: Multicultural Youth Advocacy Network, 2016).

14 Sandra M. Gifford and Edmee Kenny, "Defining Refugee Youth Settlement and Why It Matters," in Creating New 
Futures: Settling Children and Youth from Refugee Backgrounds, ed. Mary Crock (Melbourne: Federation, 2015), 118.

15 Australian Survey Research Group (ASRG), Settlement Outcomes of New Arrivals: Report of Findings (Canberra: Australian Department of Immigration and Citizenship, 2011).

16 Gifford and Kenny, "Defining Refugee Youth Settlement"; ASRG, Settlement Outcomes.

17 Marta Bivand Erdal and Ceri Oeppen, "Migrant Balancing Acts: Understanding the Interactions between Integration and Transnationalism," Journal of Ethnic and Migration Studies 39, no. 6 (2013): 871.

18 Integration is increasingly used in place of or synonymously with settlement. While it is deployed by the UNHCR and others within discourses of equity and inclusion, integration implicitly reframes the process of refugee settlement as "adaptation by outsiders to local norms." Melinda McPherson, 'II Integrate, Therefore I Am': Contesting the Normalizing Discourse of Integrationism through Conversations with Refugee Women," Journal of Refugee Studies 23, no. 4 (2010): 547 .

19 UNHCR, Integration of Resettled Refugees, 8.

20 Valtonen, "From the Margin," 87.

21 Valtonen, "From the Margin"; Gifford and Kenny, "Defining Refugee Youth Settlement."

22 Oliver Bakewell, "Research beyond the Categories: The Importance of Policy Irrelevant Research into Forced Migration," Journal of Refugee Studies 21, no. 4 (2008): 43253; McPherson, "I integrate"; Alison Strang and Alistair Ager, "Refugee Integration: Emerging Trends and Remaining Agendas," Journal of Refugee Studies, 23, no. 4 (2010): 589-607; Klaus Neumann, Sandra M. Gifford, Annika Lems, and Stefanie Scherr, "Refugee Settlement in Australia: Policy, Scholarship and the Production of Knowledge, 1952-2013," Journal of Intercultural Studies 35, no. 1 (2014): 1-17.

23 Robyn Sampson, "Caring, Contributing, Capacity Building: Navigating Contradictory Narratives of Refugee Settlement in Australia," Journal of Refugee Studies 29, no. 1 (2016): 98-116.

24 Neumann et al., "Refugee Settlement in Australia," 11.

25 Henrik Vigh, "Crisis and Chronicity: Anthropological Perspectives on Continuous Conflict and Decline," Ethnos 73, no. 1 (2008): 18.

26 Myriam Denov and Catherine Bryan, "Social Navigation and the Resettlement Experiences of Separated Children in Canada," Refuge: Canada's Journal on Refugees 30, no. 1 (2015): 25-34.

27 Vigh, "Motion Squared," 430-1.

28 Ibid., 433.

29 See, for example, Val Colic-Peisker, "At Least You're the Right Colour': Identity and Social Inclusion of Bosnian Refugees in Australia," Journal of Ethnic and Migration Studies 31, no. 4 (2005): 615-38; Caitlin Nunn, Celia McMichael, Sandra M. Gifford, and Ignacio Correa-Velez, "I Came to This Country for a Better Life': Factors Mediating
Employment Trajectories among Young People Who Migrated to Australia as Refugees during Adolescence," Journal of Youth Studies 17, no. 9 (2014): 1205-20.

30 Bakewell, "Research beyond the Categories."

31 Vigh, "Navigating Terrains." See also Andy Furlong and Fred Cartmel, Young People and Social Change: New Perspectives (Maidenhead: Open University Press, 2007).

32 Vigh, "Motion Squared," 430.

33 See, for example, Caitlin Nunn, "Spaces to Speak: Challenging Representations of Sudanese Australians," Journal of Intercultural Studies 31, no. 2 (2010): 183-98; Caitlin Nunn, Celia McMichael, Sandra M. Gifford, and Ignacio Correa-Velez, "Mobility and Security: The Perceived Benefits of Citizenship for Resettled Young People from Refugee Backgrounds," Journal of Ethnic and Migration Studies 42, no. 3 (2016): 382-99.

34 Vigh, "Motion Squared," 430.

35 Vigh, Navigating Terrains, 14.

36 Michael Leach, "Disturbing Practices': Dehumanizing Asylum Seekers in the Refugee 'Crisis' in Australia, 20012002," Refuge: Canada's Journal on Refugees 21, no. 3 (2003): 25-33; Roger Zetter, "More Labels, Fewer Refugees: Remaking the Refugee Label in an Era of Globalization," Journal of Refugee Studies 20, no. 2 (2007): 172-92.

37 Valtonen, "From the Margin."

38 Vigh, Navigating Terrains, 13.

39 Bakewell, "Research beyond the Categories."

40 Vigh, Navigating Terrains, 159.

41 Nunn et al., "I Came to This Country."'

42 Vigh, "Motion Squared," 425.

43 Ibid., 429.

44 Gifford et al., "Meaning or Measurement."

45 Ibid.; "The Good Starts Study for Resettled Refugee Youth in Australia."

46 Ignacio Correa-Velez, Sandra M. Gifford, and Celia McMichael, "The Persistence of Predictors of Wellbeing among Refugee Youth Eight Years after Resettlement in Melbourne, Australia," Social Science \& Medicine 142 (2015): 163-8.

47 The project's methodological and ethical approaches are discussed in depth elsewhere, including McMichael et al. "Studying Refugee Settlement"; Sandra M. Gifford, "To Respect or Protect? Whose Values Shape the Ethics of Refugee Research?" in Values and Vulnerabilities: The Ethics of Research with Refugees and Asylum Seekers, ed. Karen Block, Elisha Riggs, and Nick Haslam, 41-59 (Brisbane: Australian Academic Press, 2013).

48 See, for example, Nunn et al., "I Came to This Country"; Nunn et al., "Mobility and Security." A complete list of publications for the Good Starts study is available on the website: goodstarts.net/publications.html.

49 Michael Quinn Patton, Qualitative Research \& Evaluation Methods: Integrating Theory and Practice (Los Angeles: Sage Publications, 2015).

50 Helen Simons, Case Study Research in Practice (London: Sage Publications, 2009), 167. 
51 It was partway through this study, in 2011, that South Sudan gained independence from Sudan. Consequently, Matet's account does not always differentiate between Sudan and South Sudan. Therefore, following Matet's lead, this article uses Sudan to refer to either/both Sudan and South Sudan unless South Sudan is specifically referenced.

52 Zoe Robertson, Sandra M. Gifford, Celia McMichael, and Ignacio Correa-Velez, “Through Their Eyes: Seeing Experiences of Settlement in Photographs Taken by Refugee Background Youth in Melbourne, Australia," Visual Studies 31, no. 1 (2016): 34-49.

53 Marita Eastmond, "Stories as Lived Experience: Narratives in Forced Migration Research," Journal of Refugee Studies 20 no. 2 (2007): 248-64.

54 "The Special Humanitarian Program was established in 1981 within the offshore Humanitarian Programme to allow people who face human rights abuse in their home country and have a connection to the Australian community to settle permanently in Australia." Department of Immigration and Border Protection (DIBP), "The Special Humanitarian Program," https://www.border.gov.au/Trav/ Refu/Offs/The-Special-Humanitarian-Programme-(shp).

55 Nunn, "Spaces to Speak."

56 "TAFE (Technical and Further Education) is a form of tertiary education available throughout Australia which specialises in providing nationally recognised qualifications in vocational education and training." Nunn et al., "I Came to This Country."

57 It is customary in Dinka and Nuer culture for the groom to pay a dowry. This "bride price" is negotiated by the couple's families on the basis of the wealth of the groom's family and the attributes of the wife. It is traditionally paid in cattle and frequently equates to tens of thousands of dollars, placing a significant financial burden on young people.

58 Emma Stewart and Gareth Mulvey, "Seeking Safety beyond Refuge: The Impact of Immigration and Citizenship Policy on Refugees in the UK," Journal of Ethnic and Migration Studies 40, no. 7 (2014): 1023-39.

59 Department of Immigration and Border Protection (DIBP), “Temporary Protection Visas," http://www.refugeecouncil
.org.au/wp-content/uploads/2015/o8/Fact-SheetTemporary-Protection-visas.pdf.

60 Nunn et al., "Mobility and Security."

61 Cawo Abdi, "Disclaimed or Reclaimed? Muslim Refugee Youth and Belonging in the Age of Hyperbolisation," Journal of Intercultural Studies 36, no. 5 (2015): 564-78.

62 Susanne Schech, "Silent Bargain or Rural Cosmopolitanism? Refugee Settlement in Regional Australia," Journal of Ethnic and Migration Studies 40, no. 4 (2014): 601-18.

63 Nunn et al., "I Came to This Country."

64 Karin Borevi and Bo Bengtsson, "The Tension between Choice and Need in the Housing of Newcomers: A Theoretical Framework and an Application on Scandinavian Settlement Policies," Urban Studies 52, no. 14 (2015): 2599-2615.

65 Erdal and Oeppen, "Migrant Balancing Acts."

66 Vigh, "Crisis and Chronicity," 5.

67 Ibid., 8.

68 Gadi BenEzer and Roger Zetter, "Searching for Directions: Conceptual and Methodological Challenges in Researching Refugee Journeys," Journal of Refugee Studies 28, no. 3 (2014): 306-7.

Caitlin Nunn is an assistant professor (research) in the School of Applied Social Sciences at Durham University. The author may be contacted at caitlin.nunn@durham.ac.uk.

Sandra M. Gifford is a professor of anthropology in the Centre for Urban Transitions at Swinburne University of Technology. The author may be contacted at sgifford@swin.edu.au.

Celia McMichael is a lecturer in the School of Geography at the University of Melbourne. The author may be contacted at celia .momichael@unimelb.edu.au.

Ignacio Correa-Velez is associate professor of public health at the Queensland University of Technology. The author may be contacted atignacio.correavelez@qut.edu.au. 